\title{
Las dos almas de la Teología del siglo III: Tertuliano, De anima - Orígenes De principiis
}

\author{
Jerónimo Leal \\ PONTIFICIA UNIVERSITÀ DELLA SANTA CROCE \\ jleal@pusc.it
}

Tertuliano y Orígenes son dos escritores eclesiásticos casi contemporáneos, pero de mentalidades contrapuestas. Especialmente en el campo antropológico, media un abismo entre estos dos autores. Estas afirmaciones, sin embargo, dejan entre nieblas una realidad que es sustancialmente mucho más rica. El objetivo de este estudio, emprendido desde un ámbito lejano al de Orígenes, como es el de Tertuliano, es mostrar las similitudes y diferencias entre ambas posiciones en ámbito antropológico, pero restringiendo el campo de estudio - de otra manera sería prácticamente inabarcable- a la doctrina sobre el alma, punto basilar en ambos casos, y en particular en los tratados De principiis, de Orígenes, especialmente libro segundo, capítulo octavo, y De anima de Tertuliano, uno de sus tratados más extensos. Comenzaremos por la definición de alma, que ofrece un punto de partida interesante, para pasar después a algunos aspectos particulares de la antropología, con referencia al origen y naturaleza del alma, así como a la responsabilidad moral de esta y al problema de las almas separadas.

\section{DEFINICIÓN DE ALMA}

Según Orígenes ${ }^{1}$, «el alma se define de la siguiente manera: es una sus-

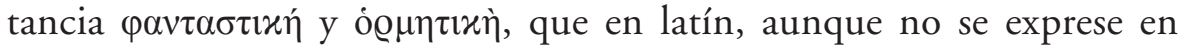
modo tan apropiado, se puede llamar sensible y movible».

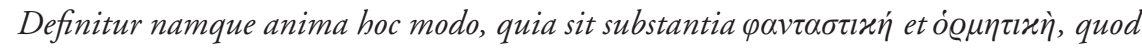
latine, licet non tam proprie explanetur, dici tamen potest 'sensibilis et mobilis'. Princ. II, 8, 1. Puede consultarse también H. Karpp, Probleme altchristlicher Anthropologie, Gütersloh 1950, 186-229. 
En esta afirmación nos encontramos, en realidad, ante dos declaraciones pertenecientes a autores diferentes. La segunda parte es una acotación de Rufino sobre la traducción latina que, aunque hipotéticamente podría facilitar la comprensión, no debe confundir al lector: volveremos sobre ella. La primera parte, en cambio, debe atribuirse al propio Orígenes y reúne dos conceptos que conviene aclarar. El primero, $\varphi \alpha \nu \tau \alpha \sigma \tau \imath x \eta ́$, hace referencia a la capacidad del alma de representar realidades; el término, que en Platón se emplea solo para designar un cierto tipo de representación artística y, por tanto, desprovisto del valor gnoseológico ${ }^{2}$, ha sido largamente empleado como una de las fases del conocimiento en ámbito estoico. El término era ya empleado por Zenón ${ }^{3}$. Nos informa Sexto Empírico de que, para los estoicos, la representación es un cambio

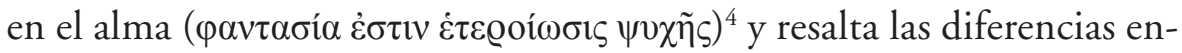
tre estoicos atribuyendo a Cleantes una teoría específica, cuando afirma:

La fantasía, por tanto, es una impresión en el alma. Sobre este punto discreparon enseguida [los estoicos]: Cleantes la entendió como depresión y relieve, como la figura que imprimen los dedos sobre la cera» ${ }^{5}$.

Y Crisipo, afirmaba: Pero donde terminan las sensaciones, ahi debe haber un alma capaz de representaciones. Estas afirmaciones explican que Rufino haya traducido el término con el latino sensibilis, más adecuado

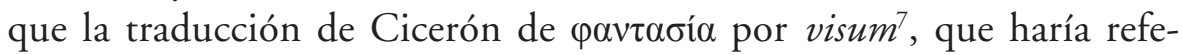
rencia únicamente a uno de los sentidos, mientras que el primero no es excluyente de ninguno de ellos.

2 Cf. Soph. 236.c.4; 236.c.7; 239.c.9; 260.d.9; 264.c.5; 267.a.8. Igualmente se emplea, casi exclusivamente en esta misma obra, el término $\varphi \alpha v \tau \alpha \sigma i ́ \alpha$ desprovisto de ese valor: cf. Soph. 260.c.9; 260.e.4; 263.d.6; 264.a.6.

3 SVFI, 55 (Cicerón, Acad. I, 40).

4 Cf. SVF II, 56.

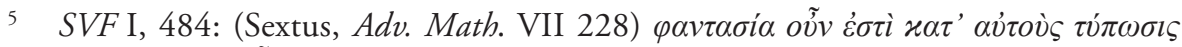

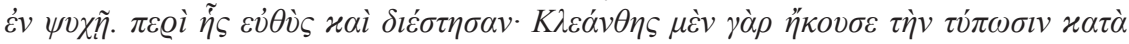

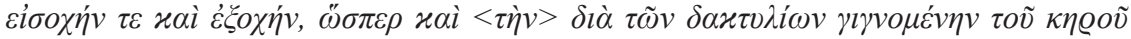
$\tau \dot{\pi} \omega \sigma \iota v$. Igual declaración se encuentra en Filón, Quod Deus sit immutabilis 9, 43

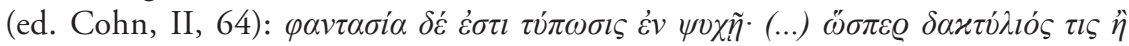

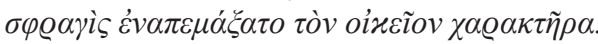

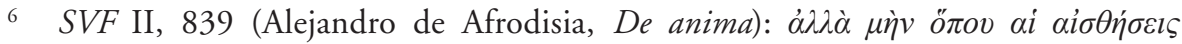

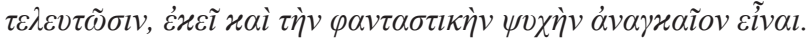

7 SVF I, 55: (Cicerón, Acad. I, 40) In qua [philosophia] primum de sensibus ipsis quaedam dixit nova, quos iunctos esse censuit e quadam quasi impulsione oblata extrinsecus, quam ille $\varphi \alpha v \tau \alpha \sigma i \alpha v$, nos visum appellemus licet. 


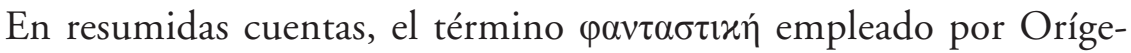
nes, es de origen evidentemente estoico y designa la capacidad del alma de emplear representaciones como paso previo al conocimiento.

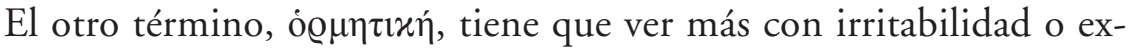
citación que con movilidad, a pesar de la traducción de Rufino, y se refiere a la interacción entre los sentidos y la razón, que se resuelve en un movimiento voluntario. Esta voz no aparece nunca en Zenón ni en Cleantes, por supuesto tampoco en Platón. Será Aecio quien nos informará sobre las teorías estoicas al respecto: Los estoicos y epicúreos [afirman que] las plantas no tienen alma. Algunos animales tienen alma impulsiva y apetitiva, otros racional. Pero las plantas se mueven de modo automático, no por acción de un almas.

Orígenes empleará en un pasaje la expresión substantia rationabiliter sensibilis et mobilis ${ }^{9}$, que prácticamente coincide con el modo de decir

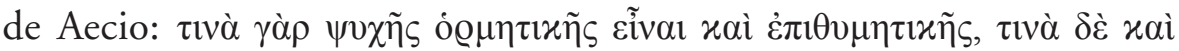
$\lambda$ оүıхп̃s. En este caso quedan dudas acerca de la conveniencia de la traducción de Rufino.

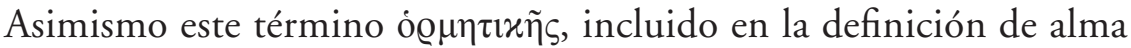
de Orígenes, tiene unos claros precedentes estoicos, mientras que no se encuentra un claro parentesco con Platón. Aunque de origen estoico, los dos elementos de la definición se encuentran ya en Filón de Alejandría:

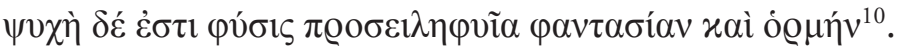

Veamos ahora qué sucede en Tertuliano.

En De anima 22, 2 encontramos una explícita definición de alma ${ }^{11}$ :

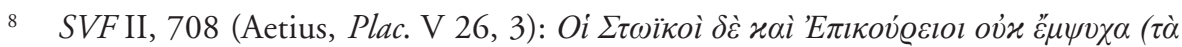

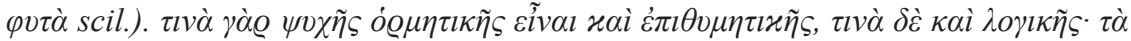
$\delta \dot{\varepsilon} \varphi v \tau \grave{\alpha} \alpha \hat{\tau} \tau o \mu \alpha \dot{\tau} \tau \omega \varsigma \pi \omega \varsigma \varkappa \imath v \varepsilon \tilde{l} \sigma \theta \alpha l$, ov̉ $\delta l \grave{\alpha} \psi v v \tilde{\eta} \varsigma$.

9 Princ. II, 8, 2: Quodsi recta ista videtur esse definitio, quod substantia rationabiliter sensibilis et mobilis anima dicatur, videtur haec eadem definitio etiam ad angelos pertinere.

10 Legum allegor. II, 7, 23 (ed. CoHN, I, 95). Cf. también Legum allegor. I, 11, 29-30

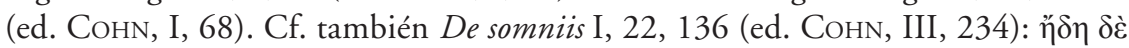

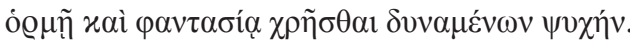

11 An. 22, 2: Definimus animam Dei flatu natam, immortalem, corporalem, effigiatam, substantia simplicem, de suo sapientem, uarie procedentem, liberam arbitrii, accidentis obnoxiam, per ingenia mutabilem, rationalem, dominatricem, diuinatricem, ex una redundantem. 
«Definimos el alma como nacida del soplo de Dios, inmortal, corporal, que se puede representar, simple por su sustancia, de suyo sapiente, que obra en diversas maneras, de voluntad libre, sometida a un origen ${ }^{12}$, mudable según los temperamentos, racional, soberana, adivina, procedente de un único origen».

Esta enumeración se debe poner en relación de oposición con la que el mismo Tertuliano da un poco más adelante ${ }^{13}$ atribuyéndola a Platón. Confrontando cada uno de los términos de ambas definiciones se pueden advertir la diferencias y puntos de contacto. De los diez primeros elementos de esta definición, seis son coincidentes entre Tertuliano y Platón, cuatro son precisamente lo contrario, la otra cara de la moneda; los siete últimos aparecen solo en Tertuliano. Es decir, que la definición del norteafricano está construida, al menos parcialmente, a partir de los datos que posee de Platón, añadiendo otros que le parecían necesarios pero no encontró en los textos del fundador de la Academia.

En efecto, los diversos elementos han sido tomados de distintos lugares, pero no siempre del mismo Platón. Los dos primeros (innata, immortalis) proceden del Fedro ${ }^{14}$. El tercer elemento (incorruptibilis) no aparece en Platón como atributo del $\mathrm{alma}^{15}$, aunque se encuentra la característica de $\dot{\alpha} \pi \alpha \theta \dot{\eta} \varsigma$, impasible, no mencionada por Tertuliano ${ }^{16}$. Los dos siguientes elementos (incorporalis, inuisibilis) aparecen en el Fedón ${ }^{17}$. El resto de las propiedades (ineffgiabilis, uniformis, principalis, rationalis, intellectualis) no se encuentra en Platón, sino que la iniciativa

12 Cf. Marc. II, 11, 2: Illa ingenita, haec accidens.

13 An. 24, 1: Innatam eam facit, quod et solum armare potuissem ad testimonium plenae diuinitatis ; adicit immortalem, incorruptibilem, incorporalem, quia hoc et Deum credidit, inuisibilem, ineffigiabilem, uniformem, principalem, rationalem, intellectualem.

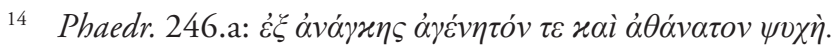

15 Para Plotino, en cambio, esta es incorruptible (Enneades III, 6, 1). Aunque posterior a Tertuliano, su testimonio acerca de las opiniones platónicas puede servir de guía.

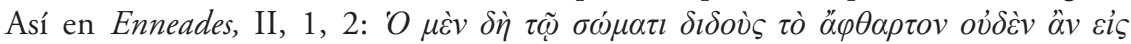

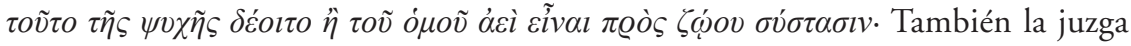
impasible ( $\alpha \pi \alpha \theta \tilde{\eta}:$ Enn. I, 1, 5).

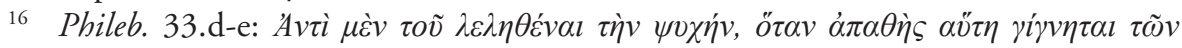

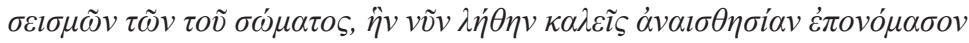

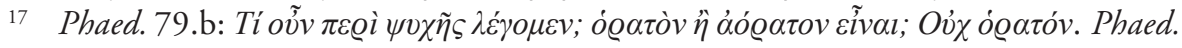

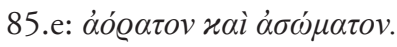


parte de Tertuliano para atribuírselas al ateniense ${ }^{18}$. Es decir, nos encontramos ante un Platón reconstruido de una manera artificial e instrumentalizado a efectos apologéticos.

Orígenes, entonces, recurre al estoicismo, a través de Filón, para definir el alma; Tertuliano, en cambio, se basa en los presupuestos platónicos para aceptar los aspectos comunes y rechazar los que son incompatibles con lo que considera doctrina cristiana. En realidad, los elementos estoicos o neoplatónicos que encontramos en ambas posturas son una adquisición de la filosofía medio-platónica, que por ser un movimiento sincretista, incorpora parcialmente las doctrinas de los otros sistemas ${ }^{19}$.

Si comparamos ahora las definiciones de Tertuliano y Orígenes apenas enunciadas, podría parecer a simple vista que no hay ni siquiera un punto en común entre ellas. No nos es lícito escamotear las dificultades de la traducción del texto de Tertuliano. Ciertamente no encontramos en este una declaración evidente de que el alma sea sensible y movible, en el sentido que hemos expuesto antes, pero algunas de las características pueden reconducirse a las mismas conclusiones de Orígenes: si el alma es de suo sapientem y rationalem requiere una serie de procesos, no especificados aquí, que deberían implicar una cierta sensibilidad, o, por el contrario, el riesgo de admitir las ideas innatas, cosa poco probable en Tertuliano; por otra parte, que el alma sea effigiatam parece indicar que sea corpórea, como lo entiende Waszink ${ }^{20}$, pero bien podría ser que Tertuliano se esté refiriendo a su capacidad de representación; de la misma manera que accidentis obnoxiam podría referirse a que está sujeta a cambio y no a que tiene un origen, como hemos traducido, puesto que esta característica ya se desprende del término natam. Una nota de las que no se incluyen en la definición más que por exclusión, passibilem, nos asegura con alta probabilidad el hecho de que Tertuliano admita esta posibilidad para el alma.

Sea como fuere, es hora ya de pasar al análisis de algunas de las convergencias y diferencias más significativas entre Orígenes y Tertuliano,

18 Algunas de estas se encuentran en otros autores como LeÓn EL FILÓSOFo (siglo IX

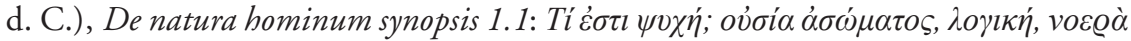

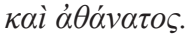

19 Una buena explicación se puede encontrar en S. Lilla, Introduzione al Medio platonismo, Roma 1992. Cf. P. HeImann, Erwähltes Schicksal. Präexistenz der Seele und christlicher Glaube im Denkmodell des Origenes, Tübingen, Theologische Beiträge und Forschungen, 1988, 52-113. 
no contenidas en la definición. Articulamos el discurso en los cuatro aspectos mencionados precedentemente.

\section{Origen del alma}

En nuestros dos autores se da una misma explicación etimológica acerca

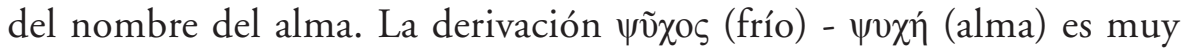
común entre los griegos, de los que podrían señalarse Platón ${ }^{21}$, Aristóteles $^{22}$, Plutarco ${ }^{23}$ y Filón ${ }^{24}$. Orígenes ${ }^{25}$ señala que el alma en la Escritura se encuentra siempre en contexto peyorativo, pero puede volver al calor. Para el alejandrino ${ }^{26}$, Dios, los ángeles y los santos son fuego, pero los que se alejan de Dios se enfrían (frigidi effecti esse), es decir, nos da una explicación de tipo espiritual.

Tertuliano, para quien frigidum nomen est anima graecorum $^{27}$, enlaza esta etimología con la narración del Génesis. Así, en An. 27, 7, afirma: Ex afflatu Dei anima. Quid aliud afflatus Dei quam uapor spiritus? Es decir, el soplo de Dios, que debe ser caliente por necesidad, es el que infunde el alma en el hombre. Tertuliano lo declara repetidamente ${ }^{28}$. En De principiis no se encuentra formulada así la procedencia del alma ${ }^{29}$, pero Orígenes discute sobre dos alternativas acerca del momento de la unión de esta con el cuerpo: extrinsecus inserta o cum corpore ficta, en I, 7,4 , declarándose partidario de la primera ${ }^{30}$, pues a su parecer la creación del hombre se divide en dos momentos diferentes entre los que

\section{Crátilo 399d/e.}

22 An. 1, 2 (405b 28/9).

23 SVF 2, 806.

24 De somn. 1, 31. Según WaszinK (Quinti Septimi Florentis Tertulliani, De anima, Edited with introduction and Commentary by J. H. WASZINK, Amsterdam 1947, 321), esta referencia fue olvidada por Von Arnim.

25 Princ. II.8.3.

26 Princ. II.8.3.

27 An. 27, 5.

28 Por ejemplo: An. 3, 4: animam ex Dei flatu, non ex materia uindicamus (...) utique ex Dei flatu, de isto nibil amplius reuoluendum...

29 Para la distinción entre nous y psyche cf. P. HEIMANn, Erwähltes Schicksal. Präexistenz der Seele und christlicher Glaube im Denkmodell des Origenes, Tübingen, Theologische Beiträge und Forschungen, 1988, 137-150.

30 Princ. I, 7, 4: Si hominis anima, quae utique inferior est, dum hominis est anima, non cum corporibus ficta, sed proprie et extrinsecus probatur inserta, multo magis eorum animantium, quae caelestia designantur. 
discurre un tiempo. La afirmación es contraria al traducianismo y parece más bien sufragar la teoría de la preexistencia de las almas. Aunque sobre el particular existe un cierto debate, podemos tomar como definitiva la opinión de Harl, quien concluye que para Orígenes las almas provienen del exterior y han sido creadas todas juntas ${ }^{31}$. Anotemos, de paso, que la preexistencia del alma es de origen filoniano y -una vez más- no platónico $^{32}$. Es interesante observar que en el mismo pasaje de Princ. I, 7, 433, Orígenes emplea los tres mismos textos bíblicos que Tertuliano en $D e$ anima 26, aunque aquí es para mostrar la vitalidad del feto, y allí para demostrar la preexistencia del alma ${ }^{34}$.

Tertuliano es partidario del traducianismo. Se pueden señalar dos razones para intentar explicar su opinión. En primer lugar, el traducianismo es un modo de argumentar en qué manera el hombre individual está unido al destino del primer hombre con su creación y caída: si solo se heredara el cuerpo, se caería en el dualismo, pues el pecado se transmitiría con la carne, única culpable, entonces, de esta transmisión. El hombre, portador a la vez de las semillas del cuerpo y el alma, transmite al embrión la culpa ya desde el momento de su concepción ${ }^{35}$. En segundo lugar, Tertuliano adopta el traducianismo también porque le parece la forma adecuada de sostener la unidad del hombre, y por eso Karpp sostiene que el traducianismo de Tertuliano no hay que reconducirlo al

31 Cf. M. Harl, La péexistence des âmes dans l'oeuvre d'Origène, en Origeniana Quarta, ed. L. LiES, Innsbruck-Wien 238-258, especialmente 252. Cf. también A. Monaci Castagno, L'idea della preesistenza delle anime e l'esegesi di RM 9, 9-21, en Origeniana secunda, ed. H. Crouzel - A. QuacQuarelli, Roma 1980, 69-78, especialmente 70-71.

32 Cf. G. Bоsтоск, The Sources of Origen's Doctrine of Pre-existence, en Origeniana Quarta, ed. L. Lies, Innsbruck-Wien 259-264, especialmente 262.

33 Princ. I, 7, 4: Nam quantum ad homines spectat, quomodo cum corpore simul ficta anima videbitur eius, qui 'in ventre fratrem suum subplantavit', id est Iacob? (Gn 25, 22) Aut quomodo simul cum corpore ficta est anima vel plasmata eius, qui adhuc in ventre matris suae positus, repletus est spiritu sancto? (Lc 1, 41) (...) Quomodo simul cum corpore ficta est et plasmata etiam illius anima, qui 'antequam in utero formaretur, notus esse dicitur deo', et 'antequam de vulva procederet, sanctificatus ab eo est?' (Ier 1, 5).

34 Cf. trad de M. Simonetti, I Principi di Origene, Torino 1979, 215, nt. 28 y pasajes allí citados.

35 "Portatore insieme, secondo la sua visione traducianista, dei semi del corpo e dell'anima, la trasmette all'embrione già dal suo primo concepimento”, G. AzZALI Bernardelli, Sangue e antropologia..., 1044 
problema del pecado original ${ }^{36}$. Prescindiendo momentáneamente de esta última afirmación, se podría sostener que se trata de dos hipótesis alternativas para explicar un único e idéntico problema: la trasmisión de la culpa originaria, dato procedente de la Revelación, se puede garantizar sea por la preexistencia de las almas, sea por el traducianismo. El otro aspecto, la unidad del compuesto humano, queda garantizado por el traducianismo y Orígenes, que no parece especialmente interesado en la unidad, deberá emplear otros argumentos.

\section{Naturaleza Del alma}

Para Orígenes, la sustancia del alma es la sangre ${ }^{37}$, como se desprende de la afirmación evidentissime 'sanguinem' omnium animalium 'animam' ipsorum esse designat ${ }^{38}$. En Tertuliano, en cambio, se produce una identificación entre caro-sanguis y corpora ${ }^{39}$. Azzali Bernardelli, ha comparado dos textos de Tertuliano en los que se define, o mejor dicho, se delimita lo que es la sangre ${ }^{40}$ : la sangre, intenta decir Tertuliano, es parte del cuerpo, por eso decir sangre es decir todo el cuerpo: la unión es íntima; tanto lo es que se trata de la médula de la unión, el vínculo indisoluble del cuerpo y el alma ${ }^{41}$.

El problema del traducianismo nos lleva de la mano al de la corporalidad. Esta, para Tertuliano, no es una propiedad del alma en sí, sino de todas las realidades, dado que pertenece al ser. Por este motivo la corporalidad influye de manera decisiva en toda la psicología de Tertuliano. Para el norteafricano, constituye un sinónimo de realidady sustancialidad. Todo lo que es realmente, es cuerpo. Solo es incorporal lo que no existe. La base de esta concepción se encuentra en el vं $\pi 0 x \varepsilon i ́ \mu \varepsilon v o v$

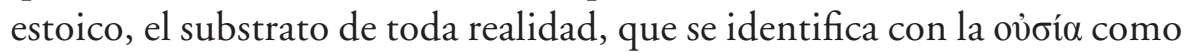
opuesta a las cualidades $(" \check{\xi} \xi \varepsilon 1 \varsigma)^{42}$. Como género del ser es necesariamente

\footnotetext{
H. KARPP, Probleme altchristlicher Anthropologie, 58-64.

Cf. H. Karpp, Probleme altchristlicher Anthropologie, Gütersloh 1950, 186.

Princ. II, 8, 1.

Res. 49, 9.

40 Se trata de Res. 28, 4 y An. 25, 4. La expresión estilística de ambos es prácticamente la misma.

41 G. Azzali Bernardelli, Sangue e antropologia biblica in Tertulliano, en Sangue e antropologia nella letteratura cristiana, Atti della settimana (Roma, 29 nov. - 4 dic. 1982), Roma 1983, 1049-51.

42 Cf. G. Esser, Die Seelenlehre Tertullians, Paderborn 1893, 65-66.
} 
corporal. A este sustrato se añaden las cualidades para formar las cosas individuales ${ }^{43}$.

Así se explica la afirmación tertulianea de que nibil est incorporale nisi quod non est ${ }^{44}$, nada es incorporal, sino lo que no existe. Dios es corpus y el alma no puede ser menos corporal. "Ser" es "cuerpo", "ser" y "cuerpo" son lo mismo ${ }^{45}$. Por eso afirma Omne, quod est, corpus est sui generis ${ }^{46}$. Tertuliano es incapaz de decir "la sustancia es" y se siente obligado a añadir siempre el predicado, explicando que "la sustancia es cuerpo" 47.

Entre los que intentan comprender a Tertuliano se encuentra S. Agustín, que afirma: Tertuliano creyó que el alma era cuerpo no por otra cosa, sino porque no pudo pensar en ella como incorpórea, y temió que no fuese nada si no se la denominaba cuerpo; por eso tampoco pudo pensar de otra manera acerca de Dios ${ }^{48}$. La opinión de que no se puede hablar de materialismo en Tertuliano, sino de corporeidad, está ya bien extendi$\mathrm{da}^{49}$, pero quizá el más claro es Seyr, cuando afirma que la diferencia del

43 Cf. M. Pohlenz, Die Stoa. Geschichte einer geistigen Bewegung, Göttingen 1948, vol. I, 69 y 294-5.

44 Carn. 11, 4.

45 Cf. I. Arnim, Stoicorum Veterum Fragmenta, Stutgardiae 1978, II, 329 y II, 359.

46 Carn. 11, 4. El alma, los ángeles y Dios, son corpus. Cf. Marc. V, 15, 8; Carn. 6, 9; Prax. 7, 8: corpus etsi spiritus est (Deus), Spiritus enim corpus sui generis.

47 Cf. J. Moingt, Théologie..., vol. II, 335

48 Denique Tertullianus, quia corpus esse animam credidit non ob aliud, nisi quod eam incorpoream cogitare non potuit et ideo timuit, ne nibil esset, si corpus non esset, nec de Deo ualuit aliter sapere, qui sane quoniam est acutus interdum contra opinionem suam uisa ueritate superatur. De Gen. ad litt. X, 25, CSEL 28, 328. Cf. también De haeresibus 86, CCL 46, 338-339.

49 Por ejemplo G. EsSER, Die Seelenlehre..., 67 afirma que se hace una injusticia a Tertuliano cuando se le tilda de materialista. También P. Siniscalco, Ricerche, 117, nota 28. Y también: "Tertulliano fin dall'epoca di Test. asserisce la corporeità dell'anima e quindi la sua passibilità, pur senza aver formulato la sua teoria così ampiamente come farà nel De anima" (P. SinISCALCO, Anima sine materia..., 116). Con otras palabras lo afirma J. Daniélou y, de acuerdo con él, J. Moingt y A. Hamman: no se trata de materialismo sino de realismo. Cf. A. Hamman, L'homme, image de Dieu. Essai..., 90. También E. WeIL, Remarques sur le "Matérialisme» des Stö̈ciens dans la coll. L'Aventure de l'EspritXIII, Sorbonne 1964, 563: «Il faudra donc parler de corporalisme, non de matérialisme.» citado por J. MoINGT, Théologie..., vol. II, 334. Cf. también G. Rauch, Der Einfluß der stoischen Philosophie auf die Lehrbildung Tertullians, Halle 1890, 19-37. Igualmente H. RONDET, «Le péché originel dans la tradition; Tertullien, Clément, Origène», en Bulletin de littérature ecclésiastique 67 (1966) 119: Tertullien n'est pas matérialiste, mais ses idées sur 
corporalismo estoico con el tertulianeo consiste en que para este hay una gran diferencia entre materia y cuerpo, mientras que para aquellos la diferencia era solo de grado: en Tertuliano el alma es de una sustancia (Stoff) tal, que no admite confusión con la materialidad ${ }^{0}$. Por lo que al motivo de tal afirmación se refiere, vale la opinión de Buonaiuti ${ }^{51}$ : la corporeidad del alma se concibe para explicar el sufrimiento de esta separada del cuerpo. Con respecto a una posible identificación entre corpus y materia, no hay que olvidar que Tertuliano se ha opuesto a Hermógenes precisamente por su opinión acerca del origen material del alma ${ }^{52}$.

Pasemos ahora a Orígenes. Aunque su modo de expresarse no es siempre evidente, de la negación del traducianismo se podría desprender su rechazo de la corporeidad. El pasaje más claro es quizá aquel en que afirma videri et videre corporum res est, cognosci et cognoscere intellectualis naturae est $t^{53}$, es decir, la naturaleza del alma es intelectual, no corporal, dado que puede conocer realidades inteligibles o no materiales ${ }^{54}$. Su argumentación pasa también por la exégesis: Appellatio autem á $\sigma \omega ́ \mu \alpha \tau o \varsigma$ (id est incorporei) non solum apud multos alios, verum etiam apud nostras scripturas inusitata est et incognita ${ }^{55}$ : la denominación de ả $\sigma \omega ́ \mu \alpha \tau o \varsigma$ (incorpóreo) es desconocida e inusitada en la Escritura.

No obstante, encontramos en Orígenes la afirmación de que los demonios tienen cuerpo, aunque no es como el nuestro - daemonici corpo-

l'âme, d'origine stö̈cienne, sont encore très grossières et son vocabulaire est aujourd'hui déconcertant.

50 F. SEYr, Die Seelen- und Erkenntnislehre..., 56-57: "Es ist bei ihnen also nur ein gradmäßiger Unterschied zwischen Geist und Materie, Seele und Leib, weil ein Übergang möglich ist von Gott zu Materie. Anders ist es bei Tertullian. Wohl ist die Seele körperlich und hat Ausdehnung, aber sie ist aus einem Stoff, der keinen Übergang zur Materie zuläßt und sie ist auf einer Seinsebene, von der es kein Absteigen zur Materie gibt".

51 Cf. E. Buonaiuti, "L'antropologia di Tertulliano», en Ricerche Religiose 3 (1927) 237.

52 Cf. Tertullien, Le mariage unique; introduction, texte critique, traduction et commentaire de P. MatteI, SCh 343, Paris 1988, 383. Mattei, en su comentario a 16, 2, hace unas consideraciones preciosas sobre las opiniones de Hermógenes: además del origen del alma a partir de la materia, se considera la sustitución de $\pi v o \eta ́$ por $\pi v \varepsilon v \tilde{\mu} \alpha$ para el relato genesíaco de la creación del hombre. Cf. también WASZINK $12^{*}$.

53 Princ. I.1.8. También Princ. I, 1, 7.

54 Además de otros pasajes, se puede citar Princ. I.1.7.

55 Princ. I, praef. 8. 
ris non est similis huic nostro crassiori et visibili- sino naturaliter subtile quoddam et velut aura tenue, et propter hoc vel putatur a multis vel dicitur incorporeum, y por eso incorporeum a simplicioribus vel imperitioribus nominatur ${ }^{56}$. Orígenes rechaza la posibilidad de un cuerpo incorpóreo, pero, a la vez, encuentra dificultades muy parecidas a Tertuliano y no tiene más remedio que referirse al cuerpo de los demonios. Por otra parte, considera que el alma es vestido (en este caso de incorruptibilidad) del cuerpo ${ }^{57}$ : Como Cristo es vestido del alma, también se puede afirmar que por cierta razón inteligible se puede decir que el alma es vestido del cuerpo. Y añade: Es su ornamento celans et contegens eius mortalem naturam, que oculta y cubre su naturaleza mortal, empleando dos verbos que se refieren al sentido de la vista y dando así una cierta corporeidad también al alma, al menos así lo afirmaría Tertuliano. Solo la expresión cierta razón inteligible puede garantizar una interpretación no estrictamente literal de sus palabras.

En esta misma línea se encuentra la interpretación de Bostock ${ }^{58}$, quien comienza señalando que en Orígenes no son lo mismo materia y cuerpo $^{59}$, que en sus escritos está presente el cuerpo espiritual ${ }^{60}$, siguiendo el texto de De principiis ${ }^{61}$, y llega incluso a afirmar que Dios mismo es corpóreo, aunque el texto de Orígenes que aduce parece afirmar más bien lo contrario: naturae divinae, quae utique principaliter incorporea est ${ }^{62}$. En realidad, el problema que suscita Orígenes es el de la compatibilidad entre la naturaleza corpórea del hombre y su ser imagen de Dios (incorpóreo), es decir, un problema parecido al que se plantea Tertuliano, si se atiende al hecho de que la imagen se debería entender como reflejo de una realidad tangible sobre otra también tangible.

56 Princ. I, praef. 8.

57 Princ. II, 3, 2: Sicut ergo Christus indumentum est animae, ita intellegibili quadam ratione etiam anima indumentum esse dicitur corporis. Ornamentum enim eius est celans et contegens eius mortalem naturam.

58 D. G. Bostock, Quality and Corporeity in Origen, en Origeniana secunda, ed. H. Crouzel - A. Quacquarelli, Roma 1980, 323-337.

59 D. G. Bоsтоск, Quality and Corporeity (...) 326.

60 D. G. Bоsтоск, Quality and Corporeity (...) 332.

${ }^{61}$ Princ. II, 3, 3: Sed quoniam non ad subitum omne indumentum corporeum effugere poterant, prius in subtilioribus ac purioribus inmorari corporibus aestimandi sunt...

62 D. G. Bostock, Quality and Corporeity (...) 337. Cf. Princ. III, 6, 1. 
Si para Orígenes el cuerpo es vestido del alma, como hemos visto ${ }^{63}$, encontramos la misma incógnita: ¡se puede vestir algo que no tenga corpus? A la vez, no es menos cierto que inpossibile est hoc ullo modo adfirmari, id est quod vivere praeter corpus possit ulla alia natura praeter Patrem et Filium et Spiritum Sanctum ${ }^{64}$ : ninguna criatura puede vivir sin el cuerpo: la unidad del compuesto está garantizada. Además, existen cuerpos espirituales ${ }^{65}$, lo cual podría parecer una contradicción. La solución podría venir por la línea de la interpretación alegórica: la necesidad que tiene el alma de despojarse (desnudarse) del pecado y del hombre viejo, tema que ha sido tratado ya en profundidad por Carla Noce ${ }^{66}$.

\section{ResponsabilidAD MORAL EN EL ALMA}

Sobre las relaciones del alma con el bien y el mal, Orígenes admite que el alma se mueve ante la presencia de un espíritu positivo, pero sin perder la conciencia, en la profecía ${ }^{67}$. De la misma manera, Tertuliano hace referencia a las visiones de una mujer de Cartago, que describe ella misma al final de las ceremonias ${ }^{68}$, como prueba de que no admite el dictado profético. En Orígenes, también los espíritus malos se pegan a los recién nacidos (mejor, a los que van a nacer, según su interpretación de la preexistencia $)^{69}$, de la misma manera que hace Tertuliano cuando afirma: a Sócrates lo manejaba fácilmente un espiritu diverso, como dicen, pues desde niño se le adhirió un demonio, maestro verdaderamente pési$m o^{70}$. La amentia ocupa un lugar similar en las posturas de Orígenes ${ }^{71} \mathrm{y}$ Tertuliano $^{72}$.

63 Sobre este aspecto, puede consultarse C. NOCE, La nudità dell'anima in Origene, in Origeniana octava, ed. L. Perrone, Leuven 2003, 679-686, especialmente 680.

64 Princ. II, 2, 2.

65 Cf. Princ. II, 2, 2.

66 C. Noce, La nudità dell'anima in Origene, in Origeniana octava, ed. L. Perrone, Leuven 2003, 679-686.

67 Cf. Princ. III, 3, 4.

68 Cf. An. 9, 3-4.

69 Cf. Princ. III, 3, 5.

70 An. 1, 4.

71 Cf. Princ. III, 3, 4.

72 Cf. An. 45, 3. 
Estas reflexiones desembocan en la consideración de la libertad. En Orígenes, es algo evidente ${ }^{73}$, una lucha entre las fuerzas de bien y del mal ante las que se encuentra el alma ${ }^{74}$. La razón que, a nuestro entender, marca la incisividad con que Orígenes defiende la existencia de la libertad es la opinión de los herejes, contraria a ella ${ }^{75}$. En el sistema origeniano, esta libertad no cesa cuando el alma se separa del cuerpo $^{76}$ : Liberi namque arbitrii semper est anima, etiam cum in corpore hoc, etiam cum extra corpus est. También en Tertuliano, el alma tiene libre potestad de

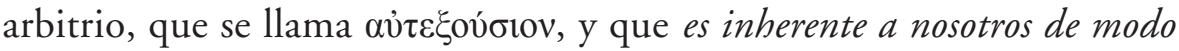
natural, -afirma- ya lo hemos mostrado contra Marción y Hermógenes ${ }^{77}$.

Esta lucha, que según Orígenes, se establece entre el bien y el mal, le conduce a admitir la posibilidad de la existencia de dos almas (sin declararse expresamente favorable) o, al menos, dos partes del alma ${ }^{78}$ (para Williams ${ }^{79}$ es más bien esta segunda opción). Una de ellas es celestial, la otra terrestre ${ }^{80}$. En Tertuliano, a pesar de sus declaraciones acerca de la unicidad ${ }^{81}$, se percibe también una cierta tendencia a la división ${ }^{82}$ : Pertenece a nuestra fe lo que Platón afirma de que el alma se divide en dos, el racional y el irracional. Nosotros aplaudimos esta definición, aunque no para que se consideren ambos como propios de la naturaleza. Se ha de creer que el racional es natural, ingénito al alma desde el comienzo, es decir, a partir de su autor racional (...) El irracional, en cambio, se ha de entender como posterior, como procedente del instinto de la serpiente, una vez que es admitida la transgresión, y de ahi crece y se desarrolla en el alma en lugar de la naturaleza...

\footnotetext{
73 Princ. II, 6, 5: Verum quoniam boni malique eligendi facultas omnibus praesto est.

74 Cf. Princ. I, praef., 5.

75 Cf. Princ. III, 1, 8.

76 Princ. III, 3, 5.

77 An. 21, 6.

78 Cf. Princ. III, 4, 1.

79 R. Williams, Origen on the Soul of Jesus, en Origeniana tertia, ed. R. Hanson - H. Crouzel, Roma 1985, 131-137, especialmente 136.

80 Princ. III, 4, 2: E quibus primo illud discutiamus, quod adstruere solent quidam, quia una sit bona in nobis anima et caelestis, alia vero inferior et terrena... La discusión se alarga hasta III, 4, 5 y concluye: Et nos quidem, prout potuimus, ex singulorum personis quae dici possent disputationis modo de singulis dogmatibus in medium protulimus; qui autem legit, eligat ex his quae magis amplectenda sit ratio

81 Cf. An. 14, 1-3.

82 An. 16, 1.
} 
Así, Orígenes parece poner el alma ante dos posibilidades, entre las que elige libremente, mientras que Tertuliano afirma su naturaleza naturalmente buena tentada por el irrationale. No obstante, en Orígenes encontramos una afirmación similar según la cual la culpa debida a la voluntad libre de la criatura, provoca la asunción de una segunda naturaleza, contraria a la primera, alia autem 'pars' ea, quae postmodum per liberi arbitrii lapsum contra naturam primae conditionis et puritatis adsumpta est, quae utique pars utpote amica et cara materiae corporalis 'cum infidelium' sorte multatur, "amiga y amada por la sustancia corpórea, que le merece la suerte de los infieles" ${ }^{83}$.

\section{El alma SEPARADA Y LA RESURRECCión}

La muerte se define como separación de alma y cuerpo por la mayor parte de los pensadores antiguos: Platón, Crisipo, Séneca, Filón, etc. ${ }^{84}$. Y las definiciones de Tertuliano de «muerte» son siempre en la misma línea: discretio corporis animaeque ${ }^{85}$; diuortium corporis ${ }^{86}$; separatio carnis atque animae ${ }^{87}$. Junto a esto, Tertuliano reconoce la inmortalidad del alma. El alma, desnuda, es expulsada del cuerpo, con una metáfora de sabor platónico, como cuando cae el auriga del carro y los caballos paran lentamente ${ }^{88}$.

En Orígenes, la certeza viene del dogma de la resurrección: si se confiesa que la resurrección es de los muertos, no cabe otra posibilidad que atribuir la muerte al cuerpo ${ }^{89}$, puesto que la resurrección es precisamente de este.

A partir de aquí, en ambos casos, el alma separada del cuerpo emprende un viaje hacia las regiones inferiores. En concreto, para Oríge-

83 G. Sfameni Gasparro, Doppia creazione e peccato di Adamo nel 'Peri Archon': fondamenti biblici e presupposti platonici dell'esegesi origeniana, en Origeniana secunda, ed. H. Crouzel - A. QuacQuarelli, Roma 1980, 57-67, especialmente 61-62. Cf. Princ. II, 10, 7.

84 J. A. Fischer, Studien zum Todesgedanken in der alten Kirche, München 1954, 26.

85 An. 51, 1.

86 An. 7, 3.

87 An. 52, 1.

88 An. 53, 1-3. La imagen es platónica. Pero obsérvese que se trata solo de imagen y no de definición del alma como auriga.

89 Princ. II, 10, 1: Si confitentur etiam ipsi quia resurrectio sit mortuorum, respondeant nobis: quid est quod mortuum est, nonne corpus? 
nes, existen las realidades del infierno y del seno de Abrahám, como contrapuestas $^{90}$. El pasaje de Princ. IV, 3, 10 es difícil, porque compara el descenso del alma a este mundo con la muerte (que es llamada infierno inferior, en contraposición al infierno de aquî).

Hay tres elementos que atraen el interés de Tertuliano: el descenso de Cristo a los infiernos o seno de Abrahám (elemento, como acabamos de ver, parcialmente común con Orígenes), la parábola de Lázaro y los himnos de los mártires. Los tres elementos tertulianeos se encuentran especialmente en la parábola de Lázaro, que contiene el conjunto de elementos del estado intermedio ${ }^{91}$. Tertuliano narra, en los capítulos 55-58 del tratado De anima ${ }^{92}$, los sucesos con que se enfrentará lo que reste del compuesto humano una vez disgregado. Las características más relevantes de esta descripción son el descenso a los infiernos a imitación de Cristo (y aquí cabría observar que hasta este extremo es cristológica la escatología del norteafricano $)^{93}$; la entrada exclusiva de los mártires en el paraíso; la detención del tiempo en los infiernos, debido a la separación del cuerpo como portador de la dimensión cronológica, conservando el sujeto la edad que tenía hasta que se opere la resurrección ${ }^{94}$; la espera que ha de sufrir el alma en tanto que se le una de nuevo el cuerpo ${ }^{95}$; el

90 Princ. IV, 3, 10: Fortassis enim sicut hi, qui de hoc mundo secundum communem istam mortem recedentes pro actibus et meritis suis dispensantur, prout digni fuerint iudicati, alii quidem in locum, qui dicitur 'inferus', alii 'in sinus Abraham' et per diversa quaeque vel loca vel mansiones: ita etiam ex illis locis velut ibi, si dici potest, morientes, a superis in hunc inferum descendunt. Nam ille inferus, ad quem hinc morientium animae deducuntur, credo ob hanc distinctionem 'inferus inferior' $a b$ scriptura nominatur, sicut dicit in psalmis: "Et liberasti animam meam de infero

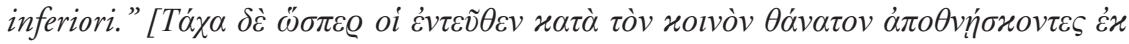

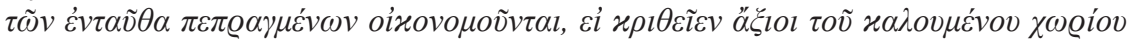

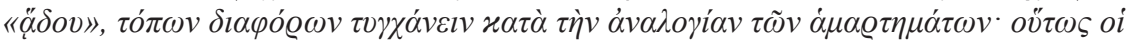

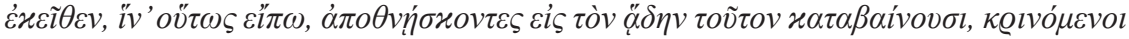

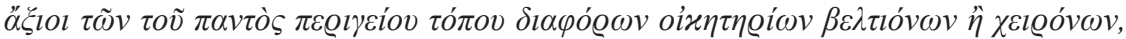

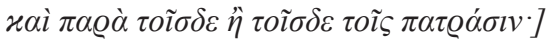

${ }^{1} C f$. H. Finé, Die Terminologie der Jenseitsvorstellungen bei Tertullian, Bonn 1958, 236.

92 Cf. An. 55, 1-58, 8.

93 Cf. An. 55, 3-5.

94 An. 56, 6.

95 Cf. An. 58, 4. 
sufrimiento en ese lugar, que será solo, y provisionalmente, por los pecados que cometió sin la carne ${ }^{96}$.

En Orígenes observamos una elaboración distinta a la de Tertuliano. En primer lugar, admite la conversión tras la muerte, al menos como hipótesis ${ }^{97}$. En efecto, Cristo es un médico que emplea curas medicinales ${ }^{98}$. Las medicinas y curas producen un dolor que sirve para la enmienda ${ }^{99}$ (adhibet ea, quae emendationis prospectu ad praesens videntur sensum doloris inferre). Pero esta enmienda es posible también después de la separación de los componentes antropológicos. Para Orígenes, el alma separada también sufre ${ }^{100}$ (circa ipsam animae substantiam tormenta quaedam ex ipsis peccatorum noxiis affectibus generantur) y la razón que aduce es que el alma tiene pasiones ${ }^{101}$, argumento que encontramos en forma parecida en el norteafricano especialmente cuando se refiere al alma carnal ${ }^{102}$.

Si en ambos autores se afirma la inmortalidad del alma, solo Orígenes parece ver la causa de esta característica: Dios ordena las almas (...) a un tiempo perpetuo y eterno, de la misma manera que Él es inmortal y eterno (...) y hace incorruptible la naturaleza que ha creado a su imagen $y$

96 Cf. An. 58, 6.

97 Princ. I, 6, 3: Iam vero si aliqui ex his ordinibus, qui sub principatu diaboli agunt ac malitiae eius obtemperant, poterunt aliquando in futuris saeculis converti ad bonitatem, pro eo quod inest in ipsis liberi facultas arbitrii, an vero permanens et inveterata malitia velut in naturam quandam ex consuetudine convertatur (...) ut opinor, hoc consequentia ipsa videtur ostendere, unamquamque rationabilem naturam posse ab uno in alterum ordinem transeuntem per singulos in omnes, et ab omnibus in singulos pervenire, dum accessus profectuum defectuumve varios pro motibus vel conatibus propriis unusquisque pro liberi arbitrii facultate perpetitur.

$98 \mathrm{Al}$ respecto, véase S. FERNÁNDEZ, Cristo médico, según Orígenes. La actividad médica como metáfora de la acción divina, Institutum Patristicum Augustinianum ("Studia Ephemeridis Augustinianum», 64), Roma 1999.

99 Princ. II, 5. 3.

100 Princ. II, 10, 4.

101 Princ. II, 10, 5: Et ne satis tibi difficilis huius rei intellectus appareat, considerari possibile est ex his passionum vitiis, quae animabus accidere solent, id est cum vel flammis amoris exuritur anima vel zeli aut livoris ignibus maceratur, aut cum irae agitatur insania vel tristitiae inmensitate consumitur, quomodo horum malorum nimietates aliquanti intolerabiliter ferentes, mortem subire quam huiuscemodi cruciatus perpeti tolerabilius habuere.

102 Cf. Carn. 10, 1. El anima carnalis es un alma hecha de carne, es decir, carnal, que atiende solo a la atracción de las pasiones. 
semejanza, es decir, ella es su imagen y semejanza ${ }^{103}$. En Tertuliano no hay una conexión entre inmortalidad e imagen-semejanza. Por eso no se encuentra en De anima una reflexión al respecto. Es más, la cuestión de la imagen y semejanza está lejos de ser clara en el cartaginés. Por un lado, si se estudian los casi treinta casos en que ambos términos aparecen unidos en todas sus obras, se puede concluir que los términos son sinónimos ${ }^{104}$. Por otro, en unos casos la imagen y semejanza se encuentra en el cuerpo, como sucedía también en Ireneo ${ }^{105}$, pero también encontramos la afirmación de que "el hombre es imagen de Dios, es decir, del Espíritu, pues Dios es Espíritu» ${ }^{106}$. Solo hay un aspecto que Tertuliano no puede admitir en la determinación de la imagen y semejanza: que ambos conceptos se distribuyan -como hacían los valentinianos- entre hombre material y hombre espiritual ${ }^{107}$.

El alejandrino establece un nexo entre la inmortalidad y la conversión: el alma, al ser inmortal y eterna, vaga por los inmensos espacios a través de los siglos y por eso le es posible no solo descender del sumo bien hasta los ínfimos males, sino también recuperarse desde los males definitivos a los sumos bienes ${ }^{108}$. En Tertuliano, la pena por las culpas menores es la mora resurrectionis, la espera de la resurrección, y no parece aceptar la conversión para el alma separada ${ }^{109}$.

En ambos casos vamos a encontrar también que una de las características del alma se transfiere al cuerpo con la resurrección: la resurrección es de un cuerpo espiritual ${ }^{110}$, en Orígenes; en Tertuliano el cuerpo es

103 Princ. III, 1, 13.

104 Cf. nuestro estudio La antropología de Tertuliano. Estudio de los tratados polémicos de los años 207-212 d. C., en Studia Ephemeridis Augustinianum 76, Roma 2001, 87-106.

105 Prax. 12, 4: Erat autem ad cuius imaginem faciebat, ad Filii scilicet, qui, homo futurus certior et uerior, imaginem suam fecerat dici hominem qui tunc de limo formari habebat, imago ueri et similitudo

106 Marc. II, 9, 3: Nam et ideo homo imago Dei, id est Spiritus; Deus enim spiritus.

107 Cf. Val. 16, 6.

108 Cf. Princ. III, 1, 23 (21).

109 Cf. A. StUiBer, Refrigerium interim. Die Vorstellungen vom Zwischenzustand und die frühchristliche Grabeskunst, Bonn 1957, 53-54. Cf. H. FinÉ, Die Terminologie der Jenseitsvorstellungen bei Tertullian, Bonn 1958, 236. Cf. J. DaniÉLou, Théologie du Judéo-Christianisme, Paris 1957, 342-344 y Les origines du christianisme latin en Histoire des doctrines chrétiennes avant Nicée Vol. III, Paris 1978, 126-127.

110 Cf. Princ. II, 10, 1. 
animal cuando se siembra, espiritual cuando resucita ${ }^{111}$. En el caso de Orígenes, el cuerpo es incorrupto también para los condenados, no solo para quienes se salvan. La condena es del hombre completo ${ }^{112}$. Solo hay una diferencia entre el alma y el cuerpo glorioso: este es visible ${ }^{113}$.

Hay, sin embargo, una divergencia notable entre los dos escritores. Para Orígenes, el cuerpo no se destruye, sino que se transforma por mérito del alma, que viene a ser entonces responsable del pecado ${ }^{114}$. Pero esta transformación, que debe identificarse con la resurrección, no se produce de un modo instantáneo, sino progresivamente, a medida que el cuerpo - por contacto con el alma, si es que se puede hablar asíalcanza la enmienda total, que termina con la destrucción de la misma muerte $^{115}$. Es decir, cuerpo y alma se transfiguran contemporáneamente conforme a sus méritos ${ }^{116}$.

En conclusión, ni Orígenes ni Tertuliano pueden escapar de los conceptos que la filosofía antigua ha ido acuñando a lo largo del tiempo. Ni siquiera estos conceptos resuelven las aporías que la reflexión cristiana ha intentado solucionar. Las diferencias entre ambos autores pueden ser numerosas y de entidad, pero conviene no olvidar las dificultades que cada uno entraña: la dificultad del lenguaje en Tertuliano, en Orígenes la hermenéutica alegórica que podría enmascarar al intérprete su auténtico pensamiento. Es preciso también profundizar en las bases medioplatónicas de ambos, pero especialmente para Orígenes, de quien no se ha hecho todavía un estudio completo al respecto, como confirma Dillon en su ya clásica monografía sobre los medio-platónicos ${ }^{117}$.

\footnotetext{
111 Cf. Res. 53, 19.

112 Cf. Princ. II, 10, 3.

113 Princ. III, 6, 4: licet caelestia sint et splendidissima corpora, 'manu facta' tamen sunt et visibilia.

114 Cf. Princ. III, 6, 5.

115 Cf. Princ. III, 6, 6.

116 Cf. Princ. III, 6, 7.

117 J. Dillon, I Medioplatonici. Uno studio sul platonismo (80 a. C.-220 d. C.), trad. italiana a cura di E. Vimercati (The Middle Platonists, London 1996), Milano 2010, 439. Un intento de la correlación entre Orígenes y el medio-platonismo se puede encontrar en el ya citado estudio de P. Heimann, Erwähltes Schicksal. Präexistenz der Seele und christlicher Glaube im Denkmodell des Origenes, Tübingen, Theologische Beiträge und Forschungen, 1988, 52-113.
} 
En ambos casos se observa una presencia de los mismos problemas a los que se suelen dar soluciones alternativas, de las cuales quizá se considere que ninguna es plenamente satisfactoria. Por eso, terminamos con una declaración de Orígenes: Nosotros, en la medida que pudimos, hemos expuesto, en forma de debate, lo que se ha podido decir sobre cada una de las doctrinas, por parte de cada una de las personas. Sin embargo, entre ellas, el que lee elija la que sea más aceptable a la razón ${ }^{118}$.

118 Princ. III, 4, 5 (ed. S. FernándeZ, en preparación). 
Resumen: El objetivo de este estudio es mostrar las similitudes y diferencias entre Orígenes y Tertuliano en ámbito de la doctrina sobre el alma. En primer lugar, trata sobre la definición de alma en ambos autores. En Orígenes la terminología es de origen estoico, en Tertuliano, en cambio, la definición es una reconstrucción arbitraria a partir de elementos platónicos. Después, se pasa a algunos aspectos particulares de la antropología, como son el origen y naturaleza del alma, la responsabilidad moral de esta y el problema de las almas separadas. En los dos autores se da una misma explicación etimológica acerca del nombre del alma, recogida de la tradición filosófica. Tertuliano enlaza esta etimología con la narración del Génesis. Orígenes discute sobre dos alternativas acerca del momento de la unión de alma y cuerpo. Tertuliano y Orígenes emplean dos hipótesis alternativas para explicar el mismo problema: la trasmisión de la culpa originaria se puede garantizar sea por la preexistencia de las almas (Orígenes), sea por el traducianismo (Tertuliano). En Tertuliano la corporalidad constituye un sinónimo de realidad y sustancialidad; Orígenes atribuye también una cierta corporeidad al alma. La libertad, en Orígenes, es algo evidente, una lucha entre las fuerzas de bien y del mal ante las que se encuentra el alma; también en Tertuliano el alma tiene libre potestad de arbitrio que es inherente al hombre de modo natural; pero mientras Orígenes parece poner el alma ante dos posibilidades, entre las que elige libremente, Tertuliano afirma que es naturalmente buena, aunque tentada por el "irrationale". En ambos autores se afirma la inmortalidad del alma, pero en Orígenes hay una conexión entre inmortalidad e imagen-semejanza, mientras que en Tertuliano no la hay. En ambos casos vamos a encontrar también que una de las características del alma se transfiere al cuerpo con la resurrección: la espiritualidad. Sin embargo, para Orígenes, el cuerpo no se destruye, como en Tertuliano, sino que se transforma por mérito del alma, que viene a ser entonces responsable del pecado.

Palabras clave: Antropología, alma, Tertuliano, Orígenes, preexistencia, traducianismo, resurrección.

Abstract: The goal of this study is to show the similarities and differences between Origen and Tertullian regarding the doctrine of the soul. In the first place, the definition of soul in both authors is discussed. In Origen the terminology is borrowed from Stoicism; in Tertullian the definition is an arbitrary reconstruction out of Platonic elements. Attention is then turned to certain aspects of anthropology, such as the origin and nature of the soul, moral responsibility, and the problem of separated souls. The two authors give the same etymological explanation of the name of the soul, gathered from the philosophical tradition. Tertullian links this etymology with Genesis. Origen discusses two alternatives regarding the moment of the union of soul and body. Tertullian and Origen employ two alternative hypotheses to explain the same problem: the transmission of original sin can be accounted for the pre-existence of souls (Origen), or by Traducianism (Tertullian). In Tertullian corporeity is synonymous with reality and substantiality; Origen also 
attributes to the soul some corporeity. Freedom, in Origen, is a struggle between the forces of good and evil in the soul. Also in Tertullian the soul has the power of free will, which inheres in man naturally. But whereas Origen seems to put the soul before two alternatives, between which it freely chooses, Tertullian says that it is naturally good, although tempted by the "irrationale". Both authors affirm the immortality of the soul, but in Origin there is a connection between immortality and image-likeness, while in Tertullian there is no such a connection. In both cases we find that one of the characteristics of the soul is transferred to the body at the resurrection: spirituality. However, for Origen, the body is not destroyed, as it is for Tertullian, but rather it is transformed through the merit of the soul, which thus becomes responsible for $\sin$.

Keywords: Anthropology, soul, Tertullian, Origen, pre-existence, Traducianism, resurrection. 
